\title{
Shifting towards an Opt-Out System in Greece: A General Practice Based Pilot Study
} \author{
Morgan $^{5}$, Roger Jones 6 \\ 1. Private Family Practice Unit in Heraklion, Crete, Greece \\ 2. Department of Social Medicine, Faculty of Medicine, University of Crete, Greece \\ 3. Private Family Practice Unit in Chania, Crete, Greece \\ 4. Primary Health Care Unit of Alonakia, Siatista, Greece \\ 5. King's College London, Dept. of Primary Care and Public Health Sciences, London, UK \\ 6. Emeritus Professor of General Practice, King's College London, UK
}

Emmanouil K. Symvoulakis ${ }^{1}$, Adelais Markaki2 ${ }^{\bowtie}$, Christos Galanakis 3 , Spyridon Klinis ${ }^{4}$, Myfanwy

$\triangle$ Corresponding author: Adelais Markaki, APRN-BC, PhD, Dept. of Social Medicine, Faculty of Medicine, Univ. of Crete, P.O. Box 2208, Heraklion, Crete, 71003. E-mail: adamarkaki@med.uoc.gr Tel. 0030-2810-394619.

() Ivyspring International Publisher. This is an open-access article distributed under the terms of the Creative Commons License (http://creativecommons.org/ licenses/by-nc-nd/3.0/). Reproduction is permitted for personal, noncommercial use, provided that the article is in whole, unmodified, and properly cited.

Received: 2013.06.27; Accepted: 2013.08.13; Published: 2013.09.0I

\begin{abstract}
New legislation in Greece towards presumed consent for organ donation, effective as of June 2013 , has come at a critical moment. This pilot study aims to explore awareness, specific concerns and intentions about the new organ donation framework among patients attending Greek general practices in a rural and urban setting. Only $2.6 \%$ of respondents had a donor card, a mere $9.6 \%$ was aware of new legislation, whereas only $3.8 \%$ considered that the public had been adequately informed. Higher income respondents were more likely to be aware that they would be considered organ donors upon death, unless declared differently. Urban practice respondents were less likely to have previously discussed with a significant other their intentions in regards to presumed consent. One quarter of all respondents (22.4\%) intended to carry out their right to prohibit organ removal upon death. Survey results reveal that organ donation reform has yet to be disseminated by the Greek society, underscoring the urgency for targeted information campaigns.
\end{abstract}

Key words: organ donation, presumed consent, opt-out, general practice, Greece

Disparities in organ donation rates exist throughout the world, even within a country, despite sharing a common legislative background [1]. Opt-out legislative systems claim to dramatically increase effective organ consent rates [2]. However there is no clear evidence that opt-out is the sole factor. A variety of other factors may interact and modify the system's effect on donation rates. Religious or cultural attitudes to body disposal, greater provision of ICU beds, incidence of road fatalities, and more pro-active donation campaigns all play an important role [1].

Presumed consent or opt-out is practiced in several countries including France, Spain, Portugal,
Belgium, Austria and Australia, yielding high donor rates $[3,4]$. Opt-out systems can be distinguished as "hard", as in Austria, where close relatives' permission is not required and "soft", as in Spain, where relatives are always asked [1]. However, even more important than the opt-in vs. opt-out system in place, is the existence of a comprehensive national procurement system, as demonstrated in the cases of Spain and Australia. Donation service changes in Spain [5], including the appointment of clinicians as transplant donor coordinators, resulted in an impressive increase from 14 donors per 1.000 .000 population ( $\mathrm{pmp}$ ) in 1989 to 35 donors pmp in just a few years [3]. Simi- 
larly, the DonateLife network in Australia is the country's coordinated effort to raise community awareness and ensure that the relatives of potential organ donors are always approached by someone specifically trained for the purpose [4].

Countries undergoing austerity measures, such as Ireland and Greece have reported dramatic swings in organ donation rates throughout the past three years $[6,7,8]$. In the case of Greece there are several indications that organ donation is still in jeopardy [9]. According to the National Transplantation Organization [8], for the first trimester of 2013 there were 1.5 donors pmp compared to 7.0 for 2012 and 7.2 for 2011, on the average. This marked decrease in donor rates has been mostly attributed to a severe reduction of ICU bed capacity throughout the country, understaffing which curtails efforts to recruit potential donors, and growing shortages in NHS as a result of the economic crisis [10]. Thus, recently voted legislative changes, initially towards a "hard" opt-out system and later modified towards a "soft" system, effective as of June 1, 2013, come at a pivotal moment.

The key role that general and family practitioners (GPs/FPs) can play in reaching out to their communities to dispel organ donation myths and reinforce positive attitudes has been the subject of a recent debate [11]. This brief communication aims to explore awareness, specific concerns and intentions about the new organ donation framework among patients attending Greek general practices in a rural and urban setting. Identifying local trends and issues among sub-groups of people facilitates the development of more targeted community campaigns and educational activities.

Patients at two primary health care (PHC) settings, a private urban general practice in Chania, Crete and a public rural general practice in Alonakia-Siatista, Northern Greece participated in the survey. Both PHC units served approximately 1,000 registered patients each. The local economy of Chania is mainly based on tourism and marine-related activities, whereas the economy of Siatista is based on agriculture and animal breeding.
A brief questionnaire comprising of six dichotomous items was developed (see Table A). The first question was similar with the one detecting donation status among ethnic groups in the UK [12]. Five more questions assessed the respondent's awareness, specific concerns and intentions towards presumed consent. Basic demographic information (age, gender, education, occupation and economic status) as well as number of chronic diseases were also recorded. Pilot testing of the tool to assess content and language clarity was performed among $10 \mathrm{PHC}$ attendants.

One GP in each primary care setting was responsible for recruiting patients. Data were collected over a 25-working-day period during the first trimester of 2013. Similarly to a previous study [13], all PHC attendants, with an appointment for any medical reason, were invited to participate except of the following categories: a) under 18 years of age, b) emergency care patients, c) persons with cognitive, motor, hearing, visual or speech disorders, and d) persons who were too sick or too elderly to participate. At the end of the consultation, eligible patients were invited to participate in the survey after being informed and assured of confidentiality and anonymity of responses. Upon obtaining written informed consent, participants were asked to complete a single-page questionnaire without any identifying information being recorded. Study approval was obtained from the Medical Council of Chania, Crete and the Ethics Committee of Kozani General Hospital.

Data were tabulated and analyzed using the SPSS 16.0 statistical package (SPSS Inc., Chicago, IL, USA). Chi square, Fisher's exact test and crude odds ratios (OR) with 95\% confidence intervals (95\% CI) were calculated to describe associations between attitudes and socio-demographic characteristics. $T$ test was also used for age means as they followed a normal distribution. Participant responses were also compared with age, gender, income, education, occupation and multi-morbidity data. P-values $<0.05$ were considered as statistically significant.

Table A. Mini assessment of GP patients' stand towards organ donation - Survey items

1. Are you registered in the national organ donor registry and do you carry a donor card?

2. Are you aware that organ donation legislation has recently changed?

3. Do you think that the public has been adequately informed about the new law in regards to organ donation and presumed consent?

4. Have you discussed with your partner, family members or friends your intentions in regards to presumed consent?

5. Are you aware that under the new law you will be instantaneously considered as an organ donor, upon death, if you have not declared differently while alive?

6. Do you intent to carry out your right to prohibit the removal of your organs upon death? 
A total of 237 PHC patients with an appointment were approached of whom 167 fulfilled the criteria and 156 of them agreed to participate $(93.4 \%$ response rate). Respondents' socio-demographic features by study setting (private vs. public and urban vs. rural) as well as survey responses are shown in Tables 1 and 2 respectively. Overall, the mean age was 56.4 years (SD: 16.1) with the majority being females $(64.1 \%)$. Seventy-three of the respondents $(46.8 \%)$ had an annual gross income of less than 10,000 euros and just over $37.2 \%(58 / 156)$ had obtained at least secondary level education.

Only $2.6 \%$ of respondents had a donor card, whereas 15/156 (9.6\%) were aware that organ donation legislation had recently changed. Very few $(6 / 156,3.8 \%)$ expressed the opinion that the public had been adequately informed about the new law in regards to organ donation and presumed consent. About one third of the respondents $(31.4 \%)$ had discussed with a partner, family member or friend their intentions in regards to presumed consent. Level of awareness that a person would be instantaneously considered as an organ donor, upon death, if he/she had not declared differently while alive, was limited $(22 / 156,14.1 \%)$. About one-quarter of respondents (35/156, 22.4\%) intended to carry out their right to prohibit the removal of their organs upon death.

Older people ( $\geq 58$ years) were less likely of being aware that under the new law they would be considered organ donors upon death, unless declared differently while alive, than their younger counterparts [(OR: 0.21; 95\% CI:0.08-0.62), Fisher's exact test, $p<0.0028]$. Patients with a gross income greater or equal to 10,000 euros had a significantly higher odds ratio of being aware that organ donation legislation had recently changed [(OR: 3.94; 95\% CI:1.19-17.8), Fisher's exact test, $p<0.0032$ ] when compared to those with lower income. Respondents attending a private urban practice were less likely to have previously discussed their intentions about presumed consent with a partner, family member or friend [(OR: 0.36; 95\% CI:0.17-0.74), chi square test, $p=0.0056]$ than those attending a rural public practice.

Pilot study findings require careful consideration, underscoring the urgency for Greek policy makers, health authorities and community leaders to proceed systematically in addressing the issues of presumed consent. Awareness about the new donation system among rural GP patients was limited $(7 \%)$, with none of the respondents perceiving the public information campaign as adequate. Nevertheless, presumed consent had been discussed with family and friends $(40.7 \%)$ and there was considerable intention to opt-out (27.9\%). Perhaps, lack of formal information, accompanied by low awareness, encourage greater informal interactions in rural, closely-knit communities, possibly leading towards greater opt-out rates. The survey's findings are in agreement with those from a recent survey among Greek medical students, where $79 \%$ claimed ignorance of existing legislation and $81.2 \%$ believed that the new law of presumed consent would cause strong reactions [14].

Presumed consent has been expected to lead towards greater transplant availability [2] although its application in situations involving children and mentally incompetent adults requires attention and intensive investigation [15]. In the case of Greece, a recent law modification has 'softened' the transition towards presumed consent, by asking for family's authorization before organ removal. However, hasty implementation of this model at a time of great economic and societal pressure is more likely to conflict with peoples' spontaneous intention for solidarity, resulting in strong sentiments. Social negativism within the wider context of national hardships, reinforced by limited information on organ donation, can seriously hinder the transition to a reformed transplantation system $[9,11]$. The disruption and strong reactions caused by social negativism or uncertainty can be seen in the undergoing initiative by the Greek Federation of Consumers (INKA) against the new law with calls to opt-out and by planning to appeal its implementation in a court of law [16]. Given that Greek policy-makers considered that defaults make a large difference in lives saved through transplantation [2], health care professionals share the responsibility of informing the public, raising community awareness, and engaging stakeholders in promotion of organ and tissue donation.

Based on the experience from other pace-setting countries, a reform of this magnitude requires a long-term dialogue, closely followed by a nationally-coordinated and culturally-sensitive campaign. The Spanish case, where the psychosocial profile of those opposing presumed consent was studied [17], as well as the recent legislative efforts in Wales to implement a new system of "deemed consent", where the burden of informing the public and raising awareness was explicitly undertaken by the government [18], pave the way towards a delicate equilibrium. Foremost, effective shifting towards an opt-out system in Greece calls for the establishment of a new level of trust among all interested parties, allowing for the gradual dispel of myths and stereotypes, dissemination of the default principles and assimilation of altruistic values by individuals and society. 
Table I: Respondent socio-demographic characteristics by primary health care setting $(n=\mid 56)$

\begin{tabular}{|c|c|c|c|c|}
\hline Socio-demographic characteristic & $\begin{array}{l}\text { Urban/Private practice } \\
\left(n_{1}=70\right)\end{array}$ & $\begin{array}{l}\text { Rural/Public practice } \\
\left(\mathrm{n}_{2}=86\right)\end{array}$ & P-value & $\begin{array}{l}\text { Total } \\
(n=156)\end{array}$ \\
\hline Mean Age (years) & $\begin{array}{l}49.0(\text { SD: 15.7) } \\
\mathrm{n}(\%)\end{array}$ & $\begin{array}{l}62.5(\text { SD: 13.7) } \\
\mathrm{n}(\%)\end{array}$ & $\mathrm{P}<0.0001$ & $\begin{array}{l}56.4 \text { (SD: 16.1) } \\
\mathrm{n}(\%)\end{array}$ \\
\hline Sex & & & NS & \\
\hline Male & $22(31.4)$ & $34(39.5)$ & & $56(35.9)$ \\
\hline Female & $48(68.6)$ & $52(60.5)$ & & $100(64.1)$ \\
\hline Education & & & $\mathrm{P}<0.0001$ & \\
\hline Illiterate & $0(0.0)$ & $4(4.7)$ & & $4(2.6)$ \\
\hline Primary & $18(25.7)$ & $51(59.3)$ & & $69(44.2)$ \\
\hline Secondary & $33(47.1)$ & $25(29.0)$ & & $58(37.2)$ \\
\hline Tertiary & $19(27.2)$ & $6(7.0)$ & & $25(16.0)$ \\
\hline Occupation & & & $\mathrm{P}<0.0001$ & \\
\hline Employed (self, by else) & $24(34.3)$ & $15(17.4)$ & & $39(25.0)$ \\
\hline Farmer & $0(0.0)$ & $30(34.9)$ & & $30(19.2)$ \\
\hline Student & $4(5.7)$ & $0(0.0)$ & & $4(2.6)$ \\
\hline Not working & $20(28.6)$ & $38(44.2)$ & & $58(37.2)$ \\
\hline Retired & $22(31.4)$ & $3(3.5)$ & & $25(16.0)$ \\
\hline Income/year (euros) & & & NS & \\
\hline$<10.000$ & $29(41.4)$ & $44(51.2)$ & & $73(46.8)$ \\
\hline$\geq 10.000$ & $41(58.6)$ & $42(48.8)$ & & $83(53.2)$ \\
\hline Associated chronic diseases & & & $\mathrm{P}<0.0059$ & \\
\hline 0 & $25(35.7)$ & $18(20.9)$ & & 43 (27.6) \\
\hline $1-3$ & $42(60.0)$ & $51(59.2)$ & & 93 (59.6) \\
\hline$\geq 4$ & $3(4.3)$ & 17 (19.9) & & $20(12.8)$ \\
\hline
\end{tabular}

T-test, chi square test were used. NS: Not statistically significant

Table 2: Item responses by primary health care setting $(n=156)$

\begin{tabular}{|c|c|c|c|}
\hline $\begin{array}{l}\text { "General Practice patients' awareness about organ transplantation in } \\
\text { Greece"- Questionnaire items }\end{array}$ & $\begin{array}{l}\text { Urban/Private practice } \\
\left(\mathbf{n}_{1}=70\right)\end{array}$ & $\begin{array}{l}\text { Rural/Public practice } \\
\left(\mathrm{n}_{2}=86\right)\end{array}$ & $\begin{array}{l}\text { Total } \\
(n=156)\end{array}$ \\
\hline & Yes / $\mathrm{n}_{1}(\%)$ & Yes / n $2(\%)$ & Yes / n (\%) \\
\hline $\begin{array}{l}\text { Q1. Are you registered in the national organ donor registry, do you carry } \\
\text { a donor card? }\end{array}$ & $2 / 70(2.9)$ & $2 / 86(2.3)$ & $4 / 156(2.6)$ \\
\hline Q2. Are you aware that organ donation legislation has recently changed? & $9 / 70(12.9)$ & $6 / 86(7.0)$ & $15 / 156(9.6)$ \\
\hline $\begin{array}{l}\text { Q3. Do you think that the public has been adequately informed about the } \\
\text { new law in regards to organ donation and presumed consent? }\end{array}$ & $6 / 70(8.6)$ & $0 / 86(0.0)$ & $6 / 156(3.8)$ \\
\hline $\begin{array}{l}\text { Q4. Have you discussed with your partner, family members or friends } \\
\text { your intentions in regards to presumed consent? }\end{array}$ & $14 / 70(20.0)$ & $35 / 86(40.7)$ & $49 / 156(31.4)$ \\
\hline $\begin{array}{l}\text { Q5. Are you aware that under the new law you will be instantaneously } \\
\text { considered as an organ donor, upon death, if you have not declared dif- } \\
\text { ferently while alive? }\end{array}$ & $11 / 70(15.7)$ & $11 / 86(12.8)$ & $22 / 156(14.1)$ \\
\hline $\begin{array}{l}\text { Q6. Do you intent to carry out your right to prohibit the removal of your } \\
\text { organs upon death? }\end{array}$ & $11 / 70(15.7)$ & $24 / 86(27.9)$ & $35 / 156(22.4)$ \\
\hline
\end{tabular}

\section{Acknowledgements}

We would like to thank Dr G. Kounis for his help in the statistical analysis.

\section{Authors' Contribution}

All authors contributed equally.

\section{Competing Interests}

The authors have declared that no competing interest exists.

\section{References}

1. [Internet] NHS Blood and Transplant. Opt in or opt out? http://www.organdonation.nhs.uk/newsroom/statements_and_stance s/statements/opt_in_or_out.asp

2. Johnson EJ, Goldstein DG. Do defaults save lives? Science. 2003;302(5649): 1338-1339.

3. [Internet] European Commission. Organ donation and transplantation: facts and figures; 9 Oct 2012 Journalists' Workshop. http://ec.europa.eu/health/blood_tissues_organs/docs/ev_20121009_f acts_figures.pdf

4. [Internet] Australian Government - Organ and Tissue Authority. Australia's organ donation rates are increasing. http://www.donatelife.gov.au/Media/docs/OTA_Performance_Updat e_10JUN11-f8408a10-8d3b-41b3-8bda-1d40f3a0cc6a-0.pdf

5. Matesanz R, Miranda B. A decade of continuous improvement in cadaveric organ donation: the Spanish model. J Nephrol. 2002 ;15(1):22-8. 
6. Houston M. Ireland has record fall in number of organ donations. BMJ. 2011;342: 982.

7. [Internet] Hunter N. Organ donation below average for 2012. Posted 26/3/2013. http://www.irishhealth.com/article.html?id=21878

8. [Internet] National Transplantation Organization (EOM). Statistical data. http:// www.eom.gr/index.php?option=com_k2\&view=item\&layout=it em\&id $=138 \&$ Itemid $=142 \&$ lang $=$ el

9. Symvoulakis EK, Markaki A, Morgan M, Jones P. Organ donation during economic hardship: an untold end for Prometheus? BMJ Rapid Response. 26-5-2011. http://www.bmj.com/rapid-response/2011/ 11/03/organ-donation-during-economic-hardship-untold-end-prometh eus

10. [Internet] Transplantations in the ICU: SOS from the Chairman of the National Transplantation Organization. http://www.ethnos.gr/ article. .asp? catid $=22768 \&$ subid $=2 \&$ pubid $=63799968$

11. Symvoulakis EK, Stavroulaki E, Morgan M, Jones R. Kidney organ donation: developing family practice intiatives to reverse inertia. BMC Health Serv Res. 2010;10:127.

12. Morgan M, Hooper R, Mayblin M, Jones R. Attitudes to kidney donation and registering as a donor among ethnic groups in the UK. Public Health (Oxf). 2006;28:226-234.

13. Symvoulakis EK, Komninos ID, Antonakis N, Morgan M, Alegakis A, Tsafantakis E, Chatziarsenis M, Philalithis A, Jones R. Attitudes to kidney donation among primary care patients in rural Crete, Greece. BMC Pub Health. 2009;9:54.

14. Dardavessis $\mathrm{T}$, Xenophontos $\mathrm{P}$, Haidich AB, Kiritsi M, Vayionas MA. Knowledge, attitudes and proposals of medical students concerning transplantations in Greece. Int J Prev Med. 2011;2(3):164-169.

15. Pierscionek BK. What is presumed when we presume consent? BMC Med Ethics. 2008;9:8.

16. [Internet] Greek Federation of Consumers (INKA). Declaration of refusal to become an organ donor. http://www.inka.gr/?cat=5

17. Conesa C, Ríos A, Ramírez P, Rodríguez MM, Rivas P, Canteras M, Parrilla P. Psychosocial Profile in Favor of Organ Donation. Transplantation Proceedings. 2003;35:1276-1281.

18. [Internet] National Assembly of Wales. National Assembly Committee agrees general principles of Human Transplantation (Wales) Bill. http://assemblywales.org/newhome/new-news-fourth-assembly.htm? act $=$ dis\&id $=244555 \& d s=4 / 2013$ 